\title{
The Sunni-Shia Conflict in the History of Islam: An Analytical Descriptive Study
}

\author{
1Abdul Manan \& 2Jovial Pally Taran \\ 1,2Universitas Islam Negeri (UIN) Ar-Raniry \\ Kopelma Darussalam, Banda Aceh, Indonesia \\ E-mail: abdul.manan@ar-raniry.ac.id
}

\begin{abstract}
This study was aimed at discussing the background of Sunni-Shia conflict in the epoch of Ottoman and Safavid Empires critically, elucidating the role of Sunni to Ottoman and depicting the role of Shia to Safavid. In this sense, this study employed a library research method through the stages of heuristics, criticism or verification, interpretation, and historiography. This research method collects historical sources in accordance with the title of the study, which is then carried out the stages of criticism of verification of the sources, and developed through the stages of interpretation or analysis, and concluded through writing history. The findings revealed that the conflict between Sunni and Shia, indeed, had ensued over a long enough period, therefore, since the era of the Rashidun Caliphate. Besides, the conflict occurring in the era of Ottoman and Safavid denoted the follow-up action of the previous ones, mainly caused by the diverse attitudes in selecting leaders, followed by the various understandings on dalil (proofs) derived from Quran and Sunnah. The difference in attitude in choosing leaders is quite big, based on tribal conflicts that have lasted quite long in the Arabian Peninsula. The conflict between Ottoman and Safavid was exacerbated by the coercion of a particular madhhab (school of thought) and the act of power seizing among them. Generally, Ottoman determined the madhhab of Hanafi as its official one. Yet, when dispute and injustice occurred, Ottoman did not halt its adherents from asking for fatwa (edict) from their own as long as they were still in the scope of Sunni madhhabs. Safavid Empire had gradually thrived applying Shia as its madhhab. The intention of Shia to seize power sparked off attempts for combat and intimidation on the ulama (Islamic scholars) and the Sunni inhabitants for them to convert their creed into Shia. To do so, there were educational institutions founded that worked to make the Shia thought spread systematically and effectively in the Safavid Empire.
\end{abstract}

Keywords: Conflict, Sunni, Shia, the History of Islam, Ottoman, Safavid

\begin{abstract}
Abstrak
Penelitian ini membahas secara kritis latar belakang konflik Sunni dan Syiah pada zaman Kerajaan Usmaniyah dan Safawiyah. Studi ini juga, menjelaskan peran Sunni terhadap Kerajaan Usmaniyah dan peran Syiah terhadap Kerajaan Safawiyah. Dengan menggunakan metode penelitian kepustakaan melalui tahapan heuristik, kritik atau verifikasi, interpretasi, dan historiografi, penelitian ini mengumpulkan sumber-sumber historis sesuai dengan judul penelitian, yang kemudian dilakukan tahapan kritik verifikasi sumber, dan dikembangkan melalui tahapan interpretasi atau analisis, dan disimpulkan melalui penulisan sejarah. Temuan mengungkapkan bahwa konflik antara Sunni dan Syiah memang telah terjadi selama periode yang cukup lama, yakni sejak era Kekhalifahan Rasyidin. Selain itu, konflik yang terjadi di era Kerajaan Usmaniyah dan Safawiyah merupakan aksi lanjutan dari sikap memilih pemimpin yang berdasarkan dari berbagai pemahaman tentang dalil Al-qur'an dan Sunnah Rasulullah. Perbedaan sikap dalam memilih pemimpin telah berlangsung cukup lama di Semenanjung CPalita: Journal of Social Religion Research. This is an open access article under the CC BY-SA 4.0 license (https://creativecommons.org/licenses/by-sa/4.0/).
\end{abstract}


Arab dan berdasarkan kesukuan. Konflik antara kedua kerajaan tersebut diperparah dengan paksaan mazhab tertentu dan tindakan kekerasan antar kerajaan. Secara umum, Kerajaan Usmaniyah menetapkan mazhab Hanafi sebagai yang mazhab resmi. Namun, ketika perselisihan dan ketidakadilan terjadi, Kerajaan Usmaniyah tidak menghentikan pengikutnya untuk meminta fatwa dari kerajaannya selama masih dalam lingkup mazhab Sunni. Kerjaan Safawiyah secara bertahap berkembang menerapkan Syiah sebagai mazhabnya. Niat Syiah untuk merebut kekuasaan memicu peperangan dan pengintimidasian ulama agar pengikut Sunni mengubah keyakinannya. Sebuah lembaga pendidikan didirikan utnuk membuat pemikiran Syiah menyebar secara sistematis dan efektif pada Kerajaan Safawiyah.

Kata Kunci,: Konflik, Sunni, Syiah, Sejarah Islam, Usmaniyah, Safawiyah

\section{Introduction}

The Middle East has various histories since its areas consist of ethnic diversities. In the past, most regions were inhabited by tribal tribes. The Middle East has a geographical position at the point where Europe, Asia and Africa meet. The name the Middle East is termed by Europeans examining the role position of their colonies during World War I and II, namely the Near East, the Middle East and the Far East. According to Lenszowsky, the Middle East politically and culturally can be divided into two main regions, the Northern Belt and the Central Arab. The former is occupied by non-Arab ethnics and has borders directly with Russia, Turkey and Iran. Meanwhile, the latter has the majority of Arab ethnics comprised of people from Saudi Arabia, Iraq, Yemen, Kuwait, Oman, Egypt, and several other Middle East countries.

Histories had recorded many events that took place behind the emergence and development of Islamic kingdoms within the tribal Arab regions. One of the events was religion polemic. It was occurred because of the Islamic parties having their sects towards Islamic teachings. The prominent ones were Sunni and Shia. The different perception of Islam, particularly in the field of ideology and politic, happened after the death of Caliph Ali ibn Abi Talib. In its historical development, Sunni and Shia often struggled with each other for their influence in an Islamic empire. Both wanted to influence in the field of religion, politics and socio-culture. The stronger the effects they have, the stronger the power that could be gathered compared with other groups. Even their influences dominated the palace, and those had a vital role in determining the policies of the government.

Both Sunni and Shia had caused many conflicts. In this study, one conflict being discussed was the event happened during the Ottoman Empire in Istanbul. The empire inhabited by the majority of Sunni became a challenge for the Safavid Empire in Iran, which was dominantly occupied by Shia people. In Sunni belief, four fiqh madhhabs - Hanafi, Maliki, Shafi'i, and Hanbali - are valid to follow. The differences among those madhhabs are not 
fundamental. It is said that the differences among them are not in terms of ushul (aqeedah), but rather in furu' (the way of worship or muamalah). Meanwhile, Shia is one of the schools of thought or madhhabs trying to follow Islam following the teachings of the Prophet Muhammad and his Ahl al-Bayt (the $\backslash$ amily of the Prophet).

Several observers from the Middle East saw the conflicts and chaos happened in the Middle East because of the different belief between Sunni and Shia people. Those clashes were then mixed up with geopolitical and geostrategic interests. The disorders were also affected by other concerns and interests of certain parties. The conflict occurring in Yemen and Syria now is also caused by the different belief between the Sunni and Shia people. Although some argued that, the West people triggered the conflict. Also, other parties claimed that it was not solely caused by sectarian conflict but rather a family conflict between the siblings, Tajul Muluk (Shia) and Rois (Sunni), which brought impact upon the sectarian violence. The conflict between the Sunni and Shia people had been started and contested since the first time of their establishments. The conflict occurred and affected the Islamic Empires, such as the Ottoman and Safavid Empires.

It could not be denied that the Sunni-Shia conflict had been going on for an extended period, including the conflict that happened between the Ottoman and Safavid Empires. It is also inseparable from differences in understanding both empires' clans. The Shi'a sect itself is as a school that was used as a royal school has experienced rapid progress, especially after the establishment of the Safavid Empire.

The establishment of the Safavid Empire, however, was inseparable from the role of Shia sect. In the past, the sect had made particular groups from the Safavid Empire. Together they wanted to issue a rebellion so that the Ottoman Empire could be destroyed and their empire could prevail. Therefore, at that time, besides fixing the internal problems, the Safavid Empire was involved in wars with the Ottoman Empires for several times in some regions. In this case, it is necessary to examine the conflict, which is actually in between the two sects and their roles within the Ottoman and Safavid Empires.

\section{Methodology}

This study applied a descriptive-analytical method with qualitative approach. The study had general and specific focuses. The general focus was to discuss the conflict caused by the Sunni and Shia since the early days of Islam and the Rashidun caliphs, while the specific focus was to elaborate the 
conflict between the two empires, the Ottoman Empire, which had based on Sunni and the Safavid Empire, which adhered Shia. Specifically, the position of both sects in the empires above was also put into account within this study. The research data were found based on the results of library research from each library and site visited. Those were collected by documenting the sources. The data analysis proposed by Miles and Huberman was then implemented towards the collected data. They were the data reduction, data verification and conclusion drawing.

\section{The Form of Sunni-Shia Leadership Conflict}

The most fundamental difference between Sunni and Shia dealt with the matters of khilafah or imamah (caliphate leadership). For Shia people, imamah is an essential and principle matter since it is a part of aqeedah. Besides, for them, imamah has a central position, and it becomes as the embodiment of lutf (grace) of the creatures made by Allah, the Almighty, of which is the same as nubuwah (prophethood). The principles contained in the aqeedah of Shia are Tawheed, nubuwah, the divine of Allah, imamah, and the day of resurrection. In fact, the matter of imamah, for Sunni people, is not completely rejected. Nevertheless, it is not an essential principle in Islam, yet it is more political and social things. ${ }^{1}$

The establishment of imamah is, in fact, to save people from evil and disobedience. That is why Allah praised a trusted caliph. This trust is called luft towards His servant. The caliph is believed to be the prophetic missionary, so he must always exist. The existence of a caliph is absolute meaning that the absence of whom should be replaced by a faqih (Islamic jurist) is necessary. The replacement will exist until the arrival of Imam alMahdi, whom the groups of faqih believe as the implication of imamah in socio-political and religious life. Conversely, among the Sunni people, there is no such teaching as practised by Shia people.

Shia people believe that imamah is not divine of Allah. None of His apostles is set for it. For Shia people, imamah is left to them to be chosen. Those who are perfect for handling situation and condition are selected as an imamah. Indeed, the chosen one should meet the specified requirements. Therefore, although the responsibility of imamah position commonly deals with religious matters, in some cases, it has business with mundane things. For that reason, the appointment of a caliph is handed over to the crowd to be discussed.

\footnotetext{
${ }^{1}$ Budhi Munawar Rahman, Doktrin Islam dan Peradaban, $2^{\text {nd }}$ Edition (Bandung: Mizan, 1995), pp. 7.
} 
The differences between Sunni and Shia as described above were due to not only different prophecies or understandings of the Quran and the Hadith, but also because of the background of Arab people. As mentioned earlier, the dominant and essential attitude for them was their loyalty to their tribe. By having such a perspective, the understanding and pride of their ancestors' achievements became the central point within the awareness of Arab people. It also turned as the benchmark for the honour and majesty of a tribe compared to other ones. ${ }^{2}$

In a rigid tribal system, as in Arab societies, their ancestors' reputation and praiseworthy deeds are the most significant source of prestige and superiority claims. Not only are their physical characteristics inherited generically, but their glory is also inherited within their lineage. ${ }^{3}$ The above socio-anthropological views towards Arab people have been suggested by Welhausen (1972), Goldziher (1967) and Nicholson (1969).

In short, the above explanations are based on these two assumptions. First, Arab people are organized societies, who are based on tribalism, loyalty and the dependency on the strength of their tribe. Second, they form the beginning of Islam adherents from two sub-cultures, namely the South Arabian and the North Central sub-cultures. ${ }^{4}$ The first assumption indicates that the social status of an individual is determined by his or her citizenship status. Every member of the citizen should always explain the deeds of their ancestors. Arab people believe that in addition to physical characteristics, behavioural appearances are also hereditary. ${ }^{5}$

There are exciting terms to be noted, khalq (physical characteristics) and khulq (behaviour characteristics). Those characteristics, particularly the behaviour ones, can become the traditions and pride of a tribe. This is commonly referred to as-Sunnah. The most cherished Sunnah is to take care of and preserve holy places. For Arab people, specifically, those who live in the Southern Arab, taking care and honouring bait (sacred places) cannot be separated. Therefore, since the era of ignorance, the Arab people did not know the separation between the temporal and sacred leaderships. Before Islam spread, Sunnah was understood as to maintain noble and ancestral policies depicted onto sturdy and magnificent buildings for their derivatives.

2 S. Husain Jafri, Origin and Early Development of Syi'ah Islam, translated. Meith Keiraha, in "Awal dan Sejarah Perkembangan Islam Syi'ah", 1 ${ }^{\text {st }}$ Edition, (Jakarta: Pustaka Hidayah, 1989), pp. 28.

${ }^{3}$ S. Husain Jafri, Origin and Early Development of Syi'ah..., pp. 30.

${ }^{4}$ Haedar Baqir, Satu Islam Sebuah Dilema, 3 ${ }^{\text {rd }}$ Edition (Bandung: Mizan, 1994), pp. 669.

${ }^{5}$ Haedar Baqir, Satu Islam Sebuah Dilema..., pp. 700. 
Similarly, after Islam spread, the embodiment of Sunnah remains; however, its contents are drastically changed to Sunnah Nubuwah. ${ }^{6}$

Kaaba is the holy house respected by all Arab tribes. The tribes who have been assigned the tasks to maintain it for generations are called the family of al-Bayt or Ahl al-Bayt. Since the beginning, the leadership among Arab people was held by Qushayy ibn Qilab. In the fight for Ahl al-Bayt, Hashemites always became the winner of their opponent, Abd a-Syam. Therefore, for Arab people, the Hashemites are known as Ahl al-Bayt. When the Umayyad descendants got a good chance, particularly when the Hashemites began to weaken, Muhammad ibn Abdullah ibn Abd Muttalib came and restored the dignity of the Hashemite as the Ahl al-Bayt. The address was then limited to the offspring of the His Messenger, Prophet Muhammad. ${ }^{7}$

In the days before Islam, the Quraysh tribe was one of the Arab clans which had a respectable position among the other clans. The glory and honour of the Quraysh people were known because of their residence, which was nearby the Kaaba and their tradition to keep it purified and guarded by them. According to Syed Ameer Ali, the oversight of the Kaaba is a hereditary succession of Prophet Ibrahim and Ismail. ${ }^{8}$ Meanwhile, in the field of religion, the genetic teachings of Islam were proceeded from generation to generation, mainly from the descendants of the Hashemites as one of Qushayy's grandchildren of $\mathrm{Ab}$ al-Manaf. Therefore, for South Arab people, to gain a noble position, this descendant has the privilege since they possess charisma in addition to having spiritual power. ${ }^{9}$

Thus, there is a belief that the holy place gas a spiritual value; the honour is deserved to put within the Hashemites as the worthy heir. When the Prophet Muhammad came, the infidelity of the Hashemites was still a success. After his revival of the Messenger of Allah and becoming as the supreme authority in Arab, he succeeded in bringing the Hashemites to the top of their power. It was proven by the surrender of Abu Sufyan upon him when the conquest of Mecca occurred.10

The Prophet realized the value of cultural aspects of the Ahl al-Bayt leadership, which combined the temporal and sacred dimensions at once. The Umayyad people, on the contrary, were unwilling and disliked towards

\footnotetext{
${ }^{6}$ S. Husain Jafri, Origin and Early Development of Syi'ah..., pp. 31.

${ }^{7}$ Budhi Munawar Rahman, Doktrin Islam dan Peradaban..., pp. 669.

${ }^{8}$ Syed Amir Ali, The Spirit of Islam (Delhi: Idarah Adabiyah, 1978), pp. 2.

${ }^{9}$ S. Husain Jafri, Origin and Early Development of Syi'ah..., pp. 32.

10 Ibid..., pp. 42.
} 
the return of the Hashemites' forces. At last, the wars of Islam most committed by the Umayyad people. ${ }^{11}$

The Prophet Muhammad also knew precisely the connection between the Prophet Ibrahim and the famous Kaaba. He also was identified as the ordinary Arab people and their four unique generations. ${ }^{12}$ All factors mentioned above are the basis of an indivisible background formation, where the replacement matter of the Prophet Muhammad should be considered. This matter, however, could not be taken into consideration from the seventh-century Arab societies since the followers of the Prophet Muhammad at the time of his death came from various parts of Arab. Accordingly, it is expected that many individuals view this problem from multiple perspectives. Two main parties that assembled people when the Prophet died were the people from North and Central Arab. The most dominant and essential tribes from those people were the Quraysh tribe, and Southern Arab people consisted of Bani Qailah. The last-mentioned tribe had two sub-tribes called Auz and Khazrah settled in Yatsrib. ${ }^{13}$

Therefore, the inclusion within the Northern Arab worshipped courage and heroism, while the inclusion in Southern Arab showed the feeling of gratitude and surrender to Allah. The people in Northern Arab elected their leaders based on the sanctity of descendants. Thus, it could be accepted that a tendency to support Ali as the Ahl al-Bayt appeared since the idea of such had existed among various Arab tribes who gathered the followers of the Prophet Muhammad in Medina. The followers consisted of the people of Mecca, both Quraysh al-Bithat (those who settled in the south of Kaaba), Quraysh alZawahir (those who lived in the suburbs) and the people of Medina (the Auz and Khazraj tribes), who had kept the characteristics of their homeland. ${ }^{14}$

From those sub-cultures, the Sunni-Shia schism appeared. It was also triggered when Mu'awiyah seized power to suppress the leadership of Ahl alBayt since the Islam doctrinally requested those adherents to put respect the Ahl al-Bayt. The disguised could not be denied by the rulers who were not regarded as the Ahl al-Bayt. They, however, did not intend to mix Islam with political interest. Supposedly, Ali once moved the capital of the Islamic government from Medina, which was ruled by the Umayyad people, to Kufa.

From those depictions, it is believed that, in addition to having acceptable different dalil believed, the Sunni and Shia also had other long historical legacies within the Arab people, of which could not be solved by the

\footnotetext{
11 Ibid..., pp. 38.

12 Ibid..., pp. 38.

13 S. Husain Jafri, Origin and Early Development of Syi'ah..., pp. 29.

14 Ibid..., pp. 28.
} 
Prophet Muhammad during his short leadership period. Even after he died, the war for getting power, which was known as Siffin War, between the Hashemites and the Umayyad people occurred.

Moreover, the intrigue of Sunni-Shia was more about primordial issues, which forced their people to look for dalil in defending their views. In this regard, if it is viewed from the perspective of Islam, Sunni and Shia are not something to adhere as a religion or belief.

Both Sunni and Shia were the parties that understood Islam and analyzed the teachings of Islam with their respective approaches and methods. As a result, those brought comparable results and debatable beliefs. Therefore, the main difference between both was ijtihad within madhhab. It was not about the principal differences. In fact, in many ways, it could not be denied that both Sunni and Shia had something in common since those parties were Muslims and from the same race. Hence, Sunni, Shia or other madhhabs had no contradiction. It is about a difference in interpreting the teachings of Islam.

If necessary, both Sunni and Shia should open themselves to their shortcomings and weaknesses. At the same time, they should respect each other, including their strengths. It must be admitted, the intellectual traditions among the Shia people were more advanced than Sunni people had. The traditions were the strengths of ta'wil (interpretation), and metaphorical understanding towards the teachings of Islam viewed from the writings of Ali Shariati. Consequently, Shia people were more speculative than the Sunni people were. They even accepted philosophy appeared. The belief made the decline of among the Sunni philosophers, while, on the contrary, the Shia philosophers kept advancing. This fact could be maziyah, a condition that should be enjoyed by both parties.

This tendency, somehow, affected the academic societies to deepen their ways of thinking, such as Murtadha Muththahhari, Sayyed Hosen Nasr, Thabaththaba'i, Ali Shariati, al-Jafri, and others. Besides, in the perspective of Islam, if Sunni and Shia were regarded as ijtihad, then huddling, blaming and dominating to each other could be avoided. The avoidance could create mutual understanding and cooperation between them as practised by famous Great Shia Marja, the late Sheikh Mahmood Syaltut and the late of Ayatullah Bowjerdi Saleh.

In the end, both Sunni and Shia rolled down fast and shared their good deeds in the social and religious lives. The history would record, judge and condemn their tracks. Since those parties were the social and historical realities, therefore, in the scientific world, the different interpretations among them were reasonable and standard. However, the unreasonable one 
was to impose one opinion on another, so the authority to express arguments would not be available. It was a wrong deed that the position of Allah, as the truth determiner, was reclaimed by humans. ${ }^{15}$

Therefore, the difference occurred between Sunni and Shia in the perspective of Islam was the undeniable (something suggested by the Prophet Muhammad and blessed by Allah). No one could argue it; even it might extend the insight, knowledge and the treasure of thought in Islam. Thus, considering Sunni and Shia were the relative thoughts or interpretations, the coercion of opinions and dominating to each other should be not committed. The absolute truth only belongs to Allah, the Almighty, not the mere humans.

\section{The Sunni-Shia Conflict during the Reign of the Ottoman and Safavid Empires Empires}

Prior to the leadership of Abbas I from the Safavid Empire, wars between Ottoman and Safavid Empires had been taken place, particularly from the reign of Ismail I until Muhammad Khudabanda. Militarily, Ismail I and his followers might face fierce hostilities from their Sunni neighbours, the Ottoman Empire in the west and Ozbeg Turkmen in the northeast. The Shah people were sufficiently able to defend their property at the Oxus border, although borders in some cities, such as Herat, Mashad and Sarakh were shiftily conquered. The attacks from Turkmen for plundering and collecting slaves kept occurring until the $19^{\text {th }}$ century AD. When achieving its glorious moments in the sixteenth century (1514 AD or $920 \mathrm{AH}$ ), specifically under the leadership of Selim, the Ottoman Empire won the war against the Safavid Empire in Chaldiran. It became a logistical victory for the Ottoman Empire. It was also a demonstration of the weaponry superiority at that time. Soon, Kurdistan, Diyarbakr and Baghdad again fell into the Ottoman Empire. Besides, Azerbaijan was also often raided by that kingdom. This made the capital of the Safavid Empire being respectively moved to Tabriz, Qazwin and Isfahan. ${ }^{16}$

Afterwards, the glorious days of the Safavid Empire took place during the supremacy of Shah Abbas I. Politically; he was able to overcome various problems in his kingdom, which disturbed the stability of the empire. He also succeeded in recapturing the territories that had been seized by other empires during the previous Safavid rulers.

15 Murtadha Muthahhari, Man and Universe, translated. Satrio Pinandito, in "Imamah dan Khilafah, $1^{\text {st }}$ Edition (Jakarta: UI Press. Firdaus, 1991), pp. 15.

16 C.E. Bosworth, The Islamic Dynasties, translated. Ilyas Hasan, in "Dinasti-Dinasti Islam" (Bandung: Mizan, 1993), pp. 197-198. 
During the end of the conflict, it can be said that the desire of Shah Abbas I to advance his kingdom with political stability where he had previously treated peace with the Ottoman Empire. However, after his progress, the opposition of the madhhab between Shia (the Safavid Empire) and Sunni (the Ottoman Empire) happened again. Even during Abbas II and Hussein, there were still disputes and repression against some Sunni scholars who eventually made some of them opt out of the kingdom.

In addition to the seizure of the territories, the conflict that occurred between the two empires above was the existence of differences in the belief adopted, in this case, the Sunni sect was believed by the Ottoman Empire, while the Safavid Empire side dominantly put trust on the Shia sect. As explained earlier, the conflict between the two sects had been taking place for a long time, even from the time of the Rashidun leaderships. It began with a political dispute related to the appropriateness of the successor to the Prophet Muhammad until it spread to the point of religious understanding.

Notably, in works of historical literature, it was not directly explained that differences in religious sects caused the basis of the conflict between the two empires. However, given the long history of Islamic history, it could be presumed that the deep-rooted conflict in the journey continued to have a long conflict due to the desire to seize influence from Muslims. Besides, it proved that the reign of power amid Muslims was realized so tempting for some people who wanted to take that influence. For this reason, the conflict between the Ottoman and Safavid Empires also moved from the conflict of the sect.

Most of the political conflicts that were currently raging in the Islamic world were also of religious background. Some of those indicated a dispute between the Sunni and Shia followers. Even, there was a conflict in Yemen, where Saudi Arabia intended to mobilize its troops to cripple the Shia Houthi group, which was supported by Iran. This action was considered a rebel.

The extension of the conflict between Sunni and Shia since the beginning of the development of Islam until now is indeed challenging to end. There is no mutual agreement produced by both globally. However, as Lutz Berger was quoted as saying on a website, there was indeed a phase where both coexisted peacefully. However, it was not as grand as the conflict itself, which continued to be exposed from time to time. 


\section{The Sunni-Shia Position within the ottoman and Safavid Empires}

\section{The Sunni position in the Ottoman Empire}

Ahl Sunnah wa al-Jama'ah (the Sunni) was presumed existed since the early days of Islam. Its teachings and interpretations were the development of the rationale that had been formulated since the period of friendship and tabi'in. Nevertheless, its religious thought was referred to the Hadith as the primary reference, after the Qur'an, of course. The name Ahlu Hadith was given instead of Ahl Sunnah wa al-Jama'ah, which at that time, was still in the process of being formed and was the antithesis of the Khawarij and Muktazilah ideology. It did not accept the Hadith as the primary source of Islamic teachings.

Furthermore, the term Ahl Sunnah wa al-Jama'ah was attributed to the Asy'ariyah and Maturidiyah schools which arose because of the reaction to the Mu'tazilite. It was first disseminated by Wasil bin Atha '(718 AD or 100 $\mathrm{AH})$. This understanding reached its peak during the Abbasid Caliph, namely al-Ma'mun (813-833 AD), al-Mu'tasim (833-842 AD) and al-Wasiq (842-847 AD). This influence was even more substantial when the Muktazilites became the official madhhab adopted by the state during the time of al-Ma'mun.

In the aftermath, the Abbasid dynasty was influenced by the Bani Saljuk of Turkey. These Seljuqites were the followers of the Sunni sect. With their influence in the government, the Bani Saljuk spread the sect understanding to the Abbasid dynasty, especially in Baghdad as a centre of power. The Sunni followers planned to eliminate the Muktazilah and Shia, which were forgiving friends. Evidently, after the influence of the government was ruled by the Children of the Saljuk, Sunni understanding began to develop until figures of the great Sunni ulama emerged at that time. Among these scholars were Imam al-Ghazali (1058-1111 AD or 450-505 AH), Imam al-Fakhrurrazi (1150-1210 AD / 544-606 AH), Abu Ishaq Ash-Shirazi (1003-1083 AD or 293-476 AH), and many other significant figures, who were influential at that period.

The disputes and fights for power between Sunni and Shia had been going on for a long time. The forerunner of that rival could be seen from the appointment of Abu Bakr as a caliph. Referring to certain Hadith, Ali and Fatima in that time were reluctant to pledge allegiance to Abu Bakr as the leader of Muslims and the successor of Prophet Muhammad. The act of reluctance could be considered as the sign of political elements in the 
ideology of a democratic state consisted of coalition and opposition groups. Unfortunately, in their historical record, those two pillars of democracy systems were failing to be formalized into a legal system in an Islamic government.

On the contrary, each sect had their theological arguments between one to another group. They misled and regarded each other as infidels. Those sects chose a dynastic or royal political system in their progress. This certainly made the political power or policy far from the consultation and democratization. The phenomenon demanded as much as possible the involvement of the communities in all guidelines issued, majorly in the reformation or maintaining political power. ${ }^{17}$

Meanwhile, the Sunni followers strained the establishment of the Umayyad, the Abbasid and the Ottoman Empires. ${ }^{18}$ At first, the Mamluk Empire, which had based in Egypt, ruled in Hijaz region (Mecca and Medina). Then, the Ottoman Empire had the power in that area. The orthodoxy of Sunni four madhhabs practised by the Mamluk Empire was applied in Hijaz. It was then influenced and kept preserved by the Ottoman Empire. The influence could be witnessed by the seriousness of the Mamluk Empire, which sent Sunni ulama in the Egyptian pilgrimage group. He acted as the khatib (preacher) and imam (leader of praying). After successfully strengthening the position of the Sunni sect in Hijaz, the Mamluk Empire began to place qadi (Sharia judge) in Haram and Nabawi Mosques to replace all janitors working in Hijaz. ${ }^{19}$ This move demonstrated that the dominance of an empire was influential on policies in various fields, including religion.

After Hijaz became as the territory of the Ottoman Empire, of which was marked by the success of Selim I in conquering Egypt in 1517 AD, the understanding of the Sunni sect also changed in a small portion. Some madhhabs could be believed during the reign of the Mamluk Empire, while only one madhhab, Hanafi, which was allowed to adhere during the governance of the Ottoman Empire. Therefore, there was only one or madhhab, who acted as qadi, in Mecca. Similar to the Mamluk Empire, the rulers of the Ottoman Empire also tried to incorporate madhhabs adhered into formal government institutions, which in this case, the Hanafi madhhab. Apart from that, if there were injustice practices in the government system happened; the residents of Hijaz were allowed to report and demand a fatwa. It should be related to the problems faced by their respective religious

17 Vali Nasr, Kebangkitan Syi'ah: Islam, Konflik dan Masa Depan (The Shia Revival: How Conflicts within Islam Will Shape the Future) (Jakarta: Diwan, 2007), pp. 20.

18 Vali Nasr, Kebangkitan Syi'ah: Islam..., pp. 24.

19 Tati Rohayati, "Kebijakan Politik Turki Utsmani di Hijaz 1512-1566 M", dalam AlTuras, Vol. XXI, No. 2, July 2015 (Online accessed on 7 November 2017), pp. 377-378. 
leaders. ${ }^{20}$ It showed that the Ottoman Empire did not curb the orthodoxy upon a madhhab in its government, even when it had legal discrepancies among its people. As long as the madhhab adhered to was still in the Sunni scope of four madhhabs, it was legitimate for the people to ask for a fatwa from other Sunni madhhab figures.

Furthermore, in terms of religion, the role of Sufism was quite strong during the reign of the Ottoman Empire in Hijaz. The military elite increasingly respected the Sufism people because they were able to explain their traditions in Egypt. According to Syafiq A. Mughni, as quoted by Tati Rohayati, the Sufism movement became an essentially religious phenomenon, particularly when the control of the Ottoman Empire in Egypt. In the beginning, several schools of Sufism order or known as tariqa had developed there, such as Khalwatiyyah, Syadziliyyah, Qadiriyyah, Rifa'iyah, Naqsabandiyyah, and other organizations under centralized leadership. The Sufism people had their role in shaping the concept of new religious life in Egyptian societies. Those could be proved with the establishment of Madrasas and the Sunni traditions like the Mawlid commemoration, where thousands of people were involved. Then, the visiting to some graves of the Islamic saints became the part of their life routines. Throughout the Ottoman Empire, the Sufism people and ulama played essential social and political roles, specifically as mediators between elites and citizens. ${ }^{21}$

The above depictions promoted that the Ottoman Empire placed the Sunni position as an important part of the communities' life. Even though the empire applied only one madhhab, it did not force its people to follow the madhhab. They even could refer to the other four madhhabs. Also, the Sufism development was regarded as a considerable influence in the Ottoman Empire. The power eventually became the identity of Sufism within the Shiffi madhhab. That was apart from the renewal movement in Hijaz around the $18^{\text {th }}$ century of AD. It made the Sufism began to erode by the renewal of Tawheed carried out by Muhammad ibn Abdul Wahab. As a result, Hijaz was quite famous for its Sufism teachings. As of last, the followers of Muhammad ibn Abdul Wahab started to campaign the changes and conflicts.

Based on that fact, it could be perceived that the relationship between the Sunni and the Ottoman Empire was indeed very close. As mentioned it its history, the Ottoman Empire had a substantial religious order. The people living in the empire believed that the traditions that had been done by them and the Sunni ulama supported the justice of them, the religious matters for

20 Tati Rohayati, “Kebijakan Politik Turki..., pp. 378.

21 Tati Rohayati, "Kebijakan Politik Turki..., pp. 378. 
the highest official religious affair. The Sunni ulama possessed the authority to give official fatwas against the religious problems that accrued in society. ${ }^{22}$

\section{The Shia position in the Safavid Empire}

The first tariqa leader, who followed the Shia sect, in the Safavid Empire, is still unknown. However, some researchers argued that Sheikh Syafi' al-Din was the first tariqa leader, who was the Sunni and Shafi'i madhhab follower. In fact, the tariqa in the Safavid Empire was originally the Sunni tariqa. Nevertheless, some said that the tariqa of the Safavid Empire spread was Shia-oriented. The significant changes in religious attitudes began to occur during the leadership of Junayd and Haedar who had political ambitions. They tended to change the tariqa they led to becoming the military and political movements.

The political obsession of Junayd and his descendants found the support from the Anatolian and Syrian Turks who joined the Safavid tariqa. They had high courage and loyalty, which later became the backbone of the Safavid Empire's military power. The belief on religion was then mixed with other views, including the extreme faith in Shia. They adored their leaders like God. It was said that the followers of Junayd called him the 'God' and his son as the 'son of God'. ${ }^{23}$

Junayd and Haedar, however, were unsuccessful in gaining political power. Both of them died in the war. The political obsession was finally brought into reality by one of Haedar's sons, Isma'il I. He was still very young when he took over the tariqa leadership of the Safavid Empire, which had been changed into militant power.

Assisted by the radical members of Qizilbash, who worshipped their leader as the incarnation of God and had willing to die for him, the young and full of ambition Isma'il I succeeded in achieving what was aspired by his father and grandfather. He defeated empires in Iran and its surroundings. He also established a new empire, known as the Safavid Empire. In 1499, the followers of Ismai'il I, including him, left Lahijan, the place where he had been caring for his childhood. They went to Ardabil and then Anatolia. In Irzinjan City (Anatolia, Turkey), he met with more tariqa followers of the Safavid Empire, who had been inactive since the death of his father around a decade earlier.

At the beginning of the Safavid Empire's establishment under leadership of the Isma'il I, the government system applied was theocratic one since his successors including him did not only claimed themselves as the

22 Badri Yatim, Sejarah Peradaban Islam (Jakarta: Raja Grafindo Persada, 1995), pp. 767.

${ }^{23}$ C.E. Bosworth, The Islamic Dynasties..., pp. 197. 
descendants of Ali, but they also regarded themselves as the incarnation of the Shia Imams. The Shia sect was unofficially used as the state religion in a country, which was dominated by the Sunni sect. The period of the Safavid Empire was so essential in Persian history due to the consolidation of Shia in that country. In the process, Persia gained a new ideal of solidarity and nationality, which made it able to enter the modern era. Persia earned its full territorial integrity and national spirit. ${ }^{24}$

During the leadership of the Safavid tariqa, the religious-political movement of its people focused more at the socio-political sector. They aimed to seize political power and establish a Shia-based country. Isma'il I was a young figure, who was ambitious in his efforts to control politics and capabilities based on the Shia doctrine. He assembled the political powers based on Shia doctrines and consolidated with the Qizilbash.

He also instructed religious officials to disseminate the teachings of Shia. The dissemination, however, was the task of them within their initial period. It was a difficult task to switch the ideology of Persian people from Sunni to Shia. This Shia switching had caused severe opposition. To realize his program, Isma'il, I did not hesitate to commit acts of violence. He also killed Sunni killers and writers who rejected the ideology of Shia. ${ }^{25}$

After the death of Isma'il I, the rulers of the Safavid Empire subsequently continued to maintain and develop their Shia madhhab. Shia educational institutions had been established during the leadership of Shah Abbas I to expand the socialization and reputation of Shia teachings. Many schools were built in Isfahan, Masyad and Siraj. One of the schools, the theological school, Khan School in Siraj (Southeast Iran) had a famous teacher named Mulla Sadra. Shah Abbas, I also had established the early education model in the next empire, Qajar. It had been offered an essential study centre in the world of Shia, particularly philosophy.

The above explanation indicated that the procession and the confession of Shia madhhab in the Safavid Empire were not the same as those that applied to the Ottoman Empire with its Sunni madhhab. Nevertheless, the conversion within the Safavid Empire becoming to Shia as a whole took place gradually. It was started from the wars triggered by the rulers of the Safavid Empire against the Sunni ulama and followers. The confrontations were campaigned to change their fates towards Shia. As a result, educational institutions were built to provide a teaching system and the spread of Shia

${ }^{24}$ Taufik Abdullah, et.al, Ensiklopedi Tematis Dunia Islam, $2^{\text {nd }}$ Edition (Jakarta: Ichtiar Baru Van Hoeve, 2002), pp. 265.

25 Abdul Karim, Sejarah Pemikiran dan Peradaban Islam, $1^{\text {st }}$ Edition (Yogyakarta: Pustaka Book Publisher, 2007), pp. 308. 
madhhab more systematic and effective. Even the existing Sunni ulama lost their trust from the communities. Although they secretly had a belief on Sunni, the Sunni ulama, who had positions in the Safavid government, were dominated by the Shia ulama in the end. It turned into the most crucial starting point for the establishment of Iranian societies today. They continue to put faith on Shia Itsna 'Ashariah as the national madhhab.

Historically, it was seen that a minority of Shia followers was able to sustain an empire by turning into something a vital part of it, specifically in terms of madhhab. It has not occurred for one kingdom only. Factually, Shia was also implemented as a royal madhhab by other empires such as Fathimiyyah, Buwaihi, Qajar, and of course, the Safavid. The tendentious spread of Shia made it unstoppable. It was similar to the historical case of Jews. In the past, they became an oppressed nation. However, the oppression made them able to move on to a high level of intellectuality. Even several world-famous figures now are Jews. Even though Jewish is categorized into small religion or community amid the world societies and other various religions, however, politically and economically, it must be admitted that Jews can be in power.

The aforementioned depictions illustrated that it could be possible for the Shia followers, in Iran, for instance, to develop their country. At this moment, Iran, with its nuclear power, can traumatize the world societies. This ultimate power is due to their desire to build knowledge and become a nation that is respected in the eyes of the world. Although Iran is famous for its controversies like political conflicts and wars, this country remains vital to boost the progress of its nation.

\section{Conclusion}

Differences in leadership attitudes that occurred in Arab countries were closely related to ethnic backgrounds of different interests. A mutual struggle over tribal influence and competition was the basis of the dispute behind the conflict of religious sects that had often been echoed so far, namely between Sunnis and Shiites.

Not many sources were obtained regarding the reasons for the conflict that occurred between the two great Ottoman and Safavid Empires. Although both adhere to different religious understandings, both Sunni and Shi'a can live in peace together. Indeed, the coercion of the Shi'a sect towards Sunni scholars in the Safavid Empire had taken place. However, this fact had never been found in historical fact in detail. Therefore, the Sunni-Shiite conflict between the two empires is challenging to trace long events that occur in 
detail-also considering that the duration of Safavid Empire was not long enough compared to the Ottomans. Moreover, in addition to dealing with external conflicts, the Safavid sultans also had to fix the empire's internal condition continuously, until one day it reached its heyday, and then suffered a setback and collapse.

The Ottoman Empire placed the Sunni position quite crucial in the level of government and the life of its people. Although it applies only one school, its government does not restrain its citizens based on one school only but can refer to the four Sunni schools. Besides, the development of Sufism also became a considerable influence during the Ottoman period, and hence Sufism itself eventually became its own identity in the Sunni schools.

Meanwhile, the Safavid Empire, with its Shia belief, had taken place progressively. The desire of Shia to fight for influence in the empire brought the situation where the wars and coercions between the Sunni ulama and followers to change their belief to Shia. It led to the establishment of educational institutions, which systematically and effectively developed the teachings of Shia within the Safavid Empire. That some Sunni ulama had lost their trust from their adherers brought an impact to the domination of ulama having authority in the empire. Most of the ulama were dominated by those who were Shia followers. Ultimately, the Safavid Empire became a key starting point for the formation of Iran as for the next kingdom.

\section{References}

Abdul Karim, Sejarah Pemikiran dan Peradaban Islam, 1st Edition, Yogyakarta: Pustaka Book Publisher, 2007.

Ali, Syed Amir, The Spirit of Islam, Delhi: Idarah Adabiyah, 1978.

Al-Musawi, A. Syarafuddin, Dialog Sunnah dan Syi'ah, translated. Muhammad al-Baqir, Bandung: Mizan, 1983.

Al-Uthaimin, Muhammad Saleh, Apakah yang Dimaksud Aqidah Ahlus Sunnah Wal Jamaah, Jakarta: Maktab Al-Muktasar Al-Islami, 1985.

Badiklat Kemhan. "Bangsa Arab". Berita Pusbahasa. Accessed on March 28, 2019.http://badiklat.kemhan.go.id/index.php/berita-pusbahasa/713bangsa-arab

Badri Yatim, Sejarah Peradaban Islam, Jakarta: Raja Grafindo Persada, 1995.

Bosworth, C.E, The Islamic Dynasties, terj. Ilyas Hasan, in "Dinasti-Dinasti Islam", Bandung: Mizan, 1993.

Budhi Munawar Rahman, Doktrin Islam dan Peradaban, 2nd Edition, Bandung: Mizan, 1995. 
Haedar Baqir, Satu Islam Sebuah Dilema, 3rd Edition, Bandung: Mizan, 1994.

Jafri, S. Husain. Origin and Early Development of Syi'ah Islam, terj. Meith Keiraha, "Awal dan Sejarah Perkembangan Islam Syi'ah", Cet. I, Jakarta: Pustaka Hidayah. 1989.

Lenczowski, George, Timur Tengah di Tengah Kancah Dunia, translated. Asgar Bixby, Bandung: Sinar Baru Algensindo, 1993.

Miles, M. B., \& Huberman, A. M. (1994). Qualitative data analysis: An expanded source book (2nd ed.). Newbury Park, CA: Sage. Muthahhari, Murtadha, Imamah dan Khilafah, terj. Satrio Pinandito, Jakarta: CV. Firdaus, 1991.

Murtadha Muthahhari, Man and Universe, translated. Satrio Pinandito, in "Imamah dan Khilafah, 1 1st Edition, Jakarta: UI Press. Firdaus, 1991.

Nasir Makarim Syirazi, Inilah Aqidah Syiah, Jakarta: al-Huda, 1423 H.

Nasr, Vali, Kebangkitan Syiah: Islam, Konflik dan Masa Depan, (The Shia Revival: How Conflicts within Islam Will Shape the Future), Jakarta: Diwan, 2007.

Pasuhuk, Hendra. "Sunni dan Syiah Bersaing Sejak Dulu”. Dunia. Accessed on November 7, 2019. http://www.dw.com/id/sunni-dan-syiah-bersaing -sejak-dulu/a-16189563

Saleh A. Nahdi, Masalah Imam Mahdi, Surabaya: Raja Pena, 1966.

Tati Rohayati, “Kebijakan Politik Turki Utsmani di Hijaz 1512-1566 M", in AlTuras, Vol. XXI, No. 2, Juli 2015 (online diakses 7 November 2017).

Taufik Abdullah, et.al, Ensiklopedi Tematis Dunia Islam, 2nd Edition, Jakarta: Ichtiar Baru Van Hoeve, 2002.

Zahir, Ihsan Ilahi, Syi'ah wa at-Tasyayyu', Lahore: Iradah Tarjuman asSunnah, 1984. Translated. Hafied Salim, Bandung: Al-Ma'arif, 1984. 